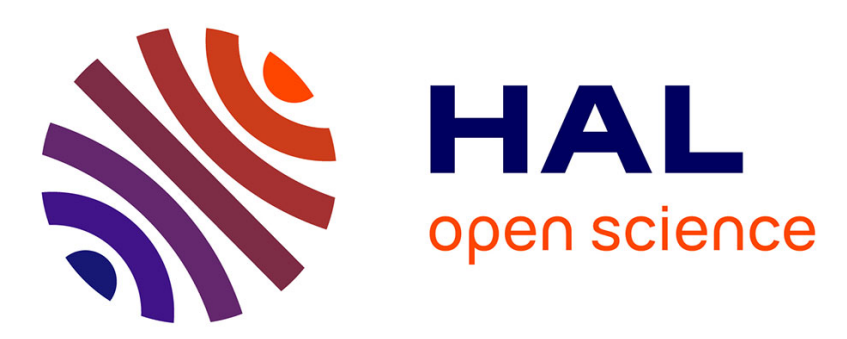

\title{
The Clarifying Reagent, or how to make the analysis of milk and dairy products easier
}

Gérard Humbert, Marie-France Guingamp, Guy Linden, Jean-Luc Gaillard

\section{To cite this version:}

Gérard Humbert, Marie-France Guingamp, Guy Linden, Jean-Luc Gaillard. The Clarifying Reagent, or how to make the analysis of milk and dairy products easier. Journal of Dairy Research, 2006, 73

(4), pp.464-471. 10.1017/S0022029906001865 . hal-02664393

\section{HAL Id: hal-02664393 \\ https://hal.inrae.fr/hal-02664393}

Submitted on 31 May 2020

HAL is a multi-disciplinary open access archive for the deposit and dissemination of scientific research documents, whether they are published or not. The documents may come from teaching and research institutions in France or abroad, or from public or private research centers.
L'archive ouverte pluridisciplinaire HAL, est destinée au dépôt et à la diffusion de documents scientifiques de niveau recherche, publiés ou non, émanant des établissements d'enseignement et de recherche français ou étrangers, des laboratoires publics ou privés. 


\title{
The Clarifying Reagent, or how to make the analysis of milk and dairy products easier
}

\author{
Gérard Humbert*, Marie-France Guingamp, Guy Linden and Jean-Luc Gaillard \\ Laboratoire des BioSciences de I'Aliment, UC INRA 885. Faculté des Sciences et Techniques. BP 239. 54506 \\ Vandoeuvre les Nancy cedex, France
}

Received 9 June 2005 and accepted for publication 8 May 2006

\begin{abstract}
Difficulties with the analysis of opaque milk and dairy products can be resolved by rendering the sample transparent. This allows direct photometric measurements of the reaction mixtures, and all sample pre-treatment steps become unnecessary. For this, several reagents have been reported in literature. Among them, the 'Clarifying Reagent' is mainly described here: its composition is given because it is now released from patenting restrictions. Its main property is a low absorbance between 340 and $800 \mathrm{~nm}$. So it can be used in many chemical and enzymatic colorimetric measurements for estimating the quality of milk and dairy products.
\end{abstract}

Keywords: milk analysis, raw milk, heated milk, cheese, clarification of milk, the Clarifying Reagent.

All raw milk components can be subject of chemical or enzymatic modifications or of degradations during storage, and so it must be processed or consumed promptly. The stability of the mineral and protein equilibrium depends on the conditions of storage, on the presence of bacteria, on the action of endogenous and exogenous enzymes. Processed milk or dairy products have to be analysed to monitor their hygienic quality for the security of the consumer and the overall quality of the product. Incidences of the technological treatment applied to the milk during a process also have to be evaluated by using chemical or enzymatic analysis of the processed milk or manufactured products.

Milk is a complex biological liquid with heterogeneous composition and 3 physical states. It is at once a solution of whey proteins, a colloidal suspension of micellar casein and an emulsion of fat in this aqueous mixture. Consequently, milk is opaque to light. Therefore, in analytical dairy laboratories, milk turbidity due to micelles of phosphocaseinate and fat globules calls for sample pretreatment by precipitation, centrifugation and filtration before spectrophotometric measurement. These preliminary steps are time-consuming, tedious and often costly.

Difficulties in the analysis of opaque milk and dairy products can be resolved by rendering samples transparent. This allows direct photometric measurements of

\footnotetext{
*For correspondence; e-mail: gerard.humbert@scbiol.uhpnancy.fr
}

the samples or reaction mixtures, and all the above preliminary sample pre-treatment steps become unnecessary.

\section{Diverse attempts at the clarification of milk}

Clarification or dissolution of samples or of reaction mixtures is not a recent objective. Table 1 reports the major dissolving reagents that have been proposed in the literature. Nakaï \& Anh Chi Le (1970) were among the first to directly determine proteins and lipids in total milk. The protein content of clarified milk and dairy products determined from absorbance at $280 \mathrm{~nm}$ of the medium is well correlated with the usual Kjeldahl method. Later Bosset et al. (1977a, b) proposed two dissolving reagents, which lead to a 0.200 residual absorbance at $500 \mathrm{~nm}$ of clarified milk sample. The major application has been the measurement of total proteins by the Biuret method (Bosset \& Blanc, 1977) for which a good correlation is obtained with Kjeldahl method.

From these precedent investigations, clarification may be defined as the result of the combined actions of solvents, detergents and base. The chemical compounds, which produce a rapid and complete dissolution of casein micelles and fat globules responsible for milk turbidity, must be miscible. The aqueous alkaline solutions of Bosset et al. $(1977 \mathrm{a}, \mathrm{b})$ are responsible of the disruption of disulphide and hydrogenous bonds, this provokes the breakdown of secondary, tertiary and quaternary structures of the proteins. The base shifts the calcium out of the micelles and consequently decreases the cohesion of this 
Table 1. Diverse chemical mixtures for the dissolution of milk

$\begin{array}{ll}\text { Reference } & \begin{array}{l}\text { Chemical composition } \\ \text { of the reagent }\end{array} \\ \text { Nakai \& Anh Chi Le, } & \text { (a) Water+acetic acid or } \\ 1970 & \text { (b) urea+imidazole }\end{array}$

Bosset et al. 1977a Water+sodium hydroxide $+n$ butylamine

Bosset et al. 1977b

Water+sodium hydroxide +tetrahydrofurane

Linden \& Pâquet, 1981 n Butylamine+cyclohexanone + Triton X-100

Owen \& Andrews, 1984

Linden et al. 1987†

The Clarifying

Reagent
Water+SDS+sodium hydroxide+Triton $\mathrm{X}-100+n$ butanone
Comments

$50 \mu \mathrm{l} \mathrm{milk}+5 \mathrm{ml}$ reagent (a) or $50 \mu \mathrm{l}$ milk $+5 \mathrm{ml}$ reagent $(\mathrm{a})+2 \cdot 5 \mathrm{ml}$ reagent (b)

Dependence on fat content

Clarification within $30 \mathrm{~min}$ at room temperature

$100 \mu \mathrm{lmilk}+5 \mathrm{ml}$ reagent

Clarification within 2 or $3 \mathrm{~min}$ at $60{ }^{\circ} \mathrm{C}$

Clarification realised before chemical measurements

$50 \mu \mathrm{l} \mathrm{milk}+5 \mathrm{ml}$ reagent

Clarification within $2 \mathrm{~min}$ at room temperature

Clarification realised before chemical measurements

$500 \mu \mathrm{lmilk}+1 \cdot 5 \mathrm{ml}$ buffered substrate $+2 \mathrm{ml}$ reagent Reagent: corrosive, viscous, malodorous and interfering with some dosages

Dilution depending on enzyme activity in the sample

Temperature around $37-40{ }^{\circ} \mathrm{C}$

Clarification realised after enzymatic reactions

Variable dilutions of milk; dependence on fat content

Variable composition of the reagent

Variable conditions of clarification: temperature up to $60{ }^{\circ} \mathrm{C}$ within time up to 60 minutes

Clarification realised before chemical measurements

Milk dilutions adapted to the

measured substance amounts

Variable ratio sample/reagent

Clarification within 3 to $5 \mathrm{~min}$ often at $37^{\circ} \mathrm{C}$, and sometimes at room temperature

Clarification realised after chemical or enzymatic measurements

See table 3 for more comments

\section{Applications}

Protein (reagent a) and fat (reagent $\mathrm{a}+\mathrm{b}$ ) determinations in milk

Milk protein (see Bosset \& Blanc, 1977)

Milk protein (see Bosset \& Blanc, 1977)

See table 2

$\mathrm{SH}, \mathrm{NH}_{2}$ and protein in milk

See table 2

†The Clarifying Reagent of Linden et al. 1987 is now released from patenting restrictions

structure and induces its dispersion. Finally, the base partially hydrolyses polypeptide chains. Milk fat globule membrane is also altered, which facilitates the dissolution of the lipids. The addition of an amphipatic solvent solubilises together lipophilic and hydrophilic components of milk. A non-ionic detergent decreases superficial tension and increases the performances of the organic solvent. All these actions lead to the breakdown of milk suspension and emulsion and milk becomes a homogenous and limpid solution.
In 1981, Linden \& Pâquet prepared on these principles a 'dissolving mixture' leading to a residual absorbance of clarified undiluted whole or skimmed milk of $0 \cdot 100$ between 400 and $800 \mathrm{~nm}$. The first application was the measurement of the alkaline phosphatase activity in pasteurised milks and creams. Subsequently, it has been applied to determine activity of 4 enzymes in milk by using specific synthetic substrates (Table 2; Linden et al. 1982; Humbert et al. 1982). It has also been used to enumerate micro-organisms in milk samples with added 
Table 2. Chemical and enzymatic protocols using the Dissolving Mixture of Linden \& Pâquet, 1981 and the Clarifying Reagent of Linden et al. (1987)

$$
\begin{aligned}
& \text { Protocols using the } \\
& \text { dissolving mixture } \\
& \text { Linden \& Pâquet, } 1981
\end{aligned}
$$

\author{
Chemical determinations \\ $\mathrm{NH}_{2}$ groups \\ $\mathrm{SH}$ groups \\ Coloured compounds $\left(\mathrm{A}_{340}\right)$ \\ Ammonia, urea
}

Enzymatic determinations

Alkaline phosphatase

Proteases

Lactoperoxidase

$\beta$-galactosidase

NAGase

Lipase

Plasmine

$\gamma$-glutamyltranspeptidase
Protocols using the Clarifying

Reagent Linden et al. 1987

Samples

Humbert et al. 1990

Guingamp et al. 1993

Guingamp et al. 1999

Guingamp et al. 1994

Linden \& Pâquet, 1981

Linden et al. 1982;

Humbert et al. 1982

Linden et al. 1982

Linden et al. 1982

+ See the present text for the modifications of these protocols allowing to substitute the "dissolving mixture" of Linden \& Pâquet, 1981 by the "Clarifying Reagent" of Linden et al. 1987

diverse bacteria strains (Kouomegne et al. 1984). However, it is corrosive, viscous, malodorous and it interferes with measurement of $\mathrm{NH}_{2}$ groups because of the presence of butylamine.

Later, Owen \& Andrews (1984) reported a clarification process independent of $\mathrm{pH}$ over the range $5 \cdot 5$ to 10.0. Below $\mathrm{pH} 5$ caseins are not maintained in solution by the reagent of clarification. The method is suitable for colorimetric measurements in the range 400 to $900 \mathrm{~nm}$. However, between 400 and $500 \mathrm{~nm}$, residual absorbance is variable depending on the sample and on the conditions used for clarification. Residual absorbance is around 0.100 at $500 \mathrm{~nm}$ for undiluted skimmed milk and 10 times diluted whole milk samples. Owen \& Andrews (1984) have proposed its use for the determination of protein by Biuret, the measurement of $\mathrm{NH}_{2}$ and $\mathrm{SH}$ groups with 2,4,6-trinitrobenzene sulphonic acid (TNBS) and 5,5'-dithiobis(2-nitrobenzoic acid) (DTNB) respectively, and the quantitation of acid phosphatase activity with NPP in milk. Stead (1987) has proposed a method to measure total proteolytic activity in milk with Hide Powder Azure as substrate after which the reaction mixture is centrifuged and clarified by the protocol of Owen \& Andrews (1984) with a delay of $30 \mathrm{~min}$ at $37{ }^{\circ} \mathrm{C}$.

Considering the different reported dissolving reagents and the properties required for obtaining a good clarification, Linden et al. (1987) have proposed and patented a reagent named The Clarifying Reagent (Table 1). Several chemical and enzymatic protocols using this Clarifying Reagent were reported for the analysis of milk and dairy products. The patent being now closed, the details of this reagent are given in the present paper.

\section{Composition and properties of The Clarifying Reagent}

The Clarifying Reagent of Linden et al. (1987) is a mixture of organic solvents and detergents which requires preparation of two solutions. The first one is $10 \mathrm{~g} \mathrm{SDS} / \mathrm{l}$ $0 \cdot 1 \mathrm{M}-\mathrm{NaOH}$. The second is a mixture $(1: 1, \mathrm{v} / \mathrm{v})$ of $n$-butanone and Triton $X-100$. The Clarifying Reagent is obtained by progressively adding 3 volumes of the second solution to 1 volume of the first.

The Clarifying Reagent has an apparent $\mathrm{pH}>13$ and a very low absorbance between 340 and $800 \mathrm{~nm}$. Clarified milk presents the same spectra as the Clarifying Reagent (Guingamp et al. 1989; Humbert et al. 1990). Absorbances are around 0.140 and 0.090 at $340 \mathrm{~nm}$ and $400 \mathrm{~nm}$ respectively. Some physical parameters of the Clarifying Reagent have been determined: its index of refraction is 1.4218 at $20{ }^{\circ} \mathrm{C}$, its conductivity is near $158 \mu$ Siemens, its viscosity is $9.75 \mathrm{cp}$ at $20^{\circ} \mathrm{C}$ and decreases to around $5 \mathrm{cp}$ at $37^{\circ} \mathrm{C}$. It may be stored at $+4{ }^{\circ} \mathrm{C}$ for 2 weeks or at $-20{ }^{\circ} \mathrm{C}$ for longer time (at least one year). The Clarifying Reagent is stable about one week at room temperature when it is stored in opaque bottle. When exposed to day light at room temperature, the Clarifying Reagent may become slightly yellow coloured; nevertheless it remains effective and there is only an increase of the absorbance of the blank assays. 
Table 3. Comments on some chemical and enzymatic protocols using the Clarifying Reagent of Linden et al. (1987)

Samples and total volume

of reaction mixture

Comments on clarification

Chemical determinations

$\mathrm{NH}_{2}$ groups Humbert

et al. 1990

SH groups Guingamp

et al. 1993

\section{Compounds $\left(\mathrm{A}_{340}\right)$}

derived of the Maillard

reactions Guingamp

et al. 1999

Ammonia Guingamp

et al. 1994
- $0.5 \mathrm{ml} 1 / 25$ to $1 / 40$ aqueous diluted milk or $0.5 \mathrm{ml} 1 / 20$ to $1 / 5010 \%(\mathrm{w} / \mathrm{v})$ aqueous cheese slurry (dilution

depends on $\mathrm{NH}_{2}$

concentration

- $\mathrm{VR}=2 \mathrm{ml}$

- $0.5 \mathrm{ml}$ milk or $1 / 1$ aqueous diluted milk if high level of $\mathrm{SH}$ groups

- VR=1.55 ml

$-1.5 \mathrm{ml} \mathrm{1/1} \mathrm{aqueous} \mathrm{diluted}$ milk

- VR=1.5 ml

- $0.4 \mathrm{ml}$ of $1 / 1$ aqueous

diluted milk

- $\mathrm{VR}=1 \cdot 42 \mathrm{ml}$
3-5 min

- LS=30 min

Clarifying Reagent

- LS=20 min depends on it

- LS=20 min
Enzymatic determinations

Alkaline phosphatase Blel et al. 2002
- Previous acidification with $0.5 \mathrm{ml}$ acid acetic solution before addition of $1.5 \mathrm{ml}$ Clarifying

Reagent to avoid alkaline

hydrolysis of residual TNBS,

clarification at $37^{\circ} \mathrm{C}$ within

- Reaction with DTNB at room

temperature but clarification is

processed at $37^{\circ} \mathrm{C}(3-5 \mathrm{~min})$ with

$0.5 \mathrm{ml}$ EDTA solution and $2 \mathrm{ml}$ of

- Dependence of fat content

- Clarification with $2 \cdot 4 \mathrm{ml}$ Clarifying Reagent, at $37{ }^{\circ} \mathrm{C}$ (5-7 min)

- Necessary to know fat content of the sample because absorbance

- Enzymatic reaction occurs at room temperature but clarification requires 5 min at $37{ }^{\circ} \mathrm{C}$

- Clarification is easier with addition of

$1 \mathrm{ml}$ EDTA solution before addition of $1.5 \mathrm{ml}$ Clarifying Reagent

- LS=20 min

- Clarification in 3 min at $37{ }^{\circ} \mathrm{C}$ with $2 \mathrm{ml}$ Clarifying Reagent

- $0.5 \mathrm{ml}$ aqueous diluted or not according to the level of activity

- VR=2.0 ml
Repeatability CV (\%)

Correlation with reference method

$\mathrm{CV}=3 \cdot 05 n=32$

$r=0.995 ; n=32$

Ninhydrin (More \& Stein, 1954)

$\mathrm{CV}=3 \cdot 2 n=30$

$r=0.994 ; n=15$

Amperometry (Yoshino et al. 1962)

$\mathrm{CV}=3 \cdot 1 n=32$ (on a pasteurised milk sample)

$\mathrm{CV}=5 \cdot 4 \quad n=26$

\section{No similar method}

Correlation with lactulose measured with Capillary Electrophoresis on raw and different heated milk samples (Guingamp et al. 1999) $r=0.91 ; n=31$

$r=0.99 ; n=19$

Specific electrode (Hélaine, 1977) $r=0.98 ; n=28$

p-n-itrophenylphosphate (IDF

1987) 
Proteases, adapted from protocol of Humbert et al. 1982

- $0.5 \mathrm{ml}$ milk or dilution of $5 \%(\mathrm{w} / \mathrm{v})$ aqueous cheese slurry

- VR=2.0 m

NAGase Humbert et al 1995

$-0.2 \mathrm{ml} \mathrm{milk}$

$-\mathrm{VR}=0.5 \mathrm{ml}$

Lipase Humbert

et al. 1997

$-0.5 \mathrm{ml}$ aqueous diluted or of activity, or aqueous $2 \%$ $(\mathrm{w} / \mathrm{v})$ cheese slurry

- $\mathrm{VR}=2.55 \mathrm{ml}$

Lactoperoxidase Blel et al. 2001

$\gamma$-glutamyl

transpeptidase

Blel et al. 2002

$$
\begin{aligned}
& \text { - } 0.25 \mathrm{ml} 1 / 5 \text { raw milk diluted } \\
& \text { with boiled milk (more } \\
& \text { dilution if high activity) } \\
& -\mathrm{VR}=2 \cdot 45 \mathrm{ml} \\
& -0.1 \mathrm{ml} \text { milk, diluted with } \\
& \text { boiled milk if high activity, } \\
& \text { no dilution for aqueous } \\
& 5 \%(\mathrm{w} / \mathrm{v}) \text { cheese slurry }
\end{aligned}
$$

- VR=2.1 ml not according to the level
- Clarification in $3 \mathrm{~min}$ at $37^{\circ} \mathrm{C}$ with $2 \mathrm{ml}$ Clarifying Reagent

- LS=15 min

- Enzymatic reaction at $50{ }^{\circ} \mathrm{C}$

- The reaction is better stopped and clarification is improved with addition of $1.5 \mathrm{ml}$ solution EDTA before $1 \mathrm{ml}$ Clarifying Reagent,

2-4 min at room temperature or short time at $37^{\circ} \mathrm{C}$

- LS=20 min $37^{\circ} \mathrm{C}$ before addition of substrate for the enzymatic reaction

- The reaction is better stopped with $0.4 \mathrm{ml}$ addition of an inhibiting mixture (EDTA, PMSF, DMF)

- Clarification with $2 \mathrm{ml}$ of Clarifying Reagent within $3-5 \mathrm{~min}$ at $37^{\circ} \mathrm{C}$

- LS=15 min

- Very short time of reaction: $20 \mathrm{sec}$ for milk and $40 \mathrm{sec}$ for cheese

- Clarification with $2 \mathrm{ml}$ Clarifying Reagent, after $2 \mathrm{~min}$ at $37^{\circ} \mathrm{C}$

- LS=10 min

- Clarification with $2 \mathrm{ml}$ Clarifying Reagent at $37^{\circ} \mathrm{C}$ within 2 min for milk and 5 min for cheese slurry

- LS=10 min
- Required 15 min pre-incubation at
$\mathrm{CV}=3 \cdot 0 n=33$

$C V=3 \cdot 25 n=20$

$\mathrm{CV}=5 \cdot 2 n=33$

$\mathrm{CV}=3 \cdot 0 n=20$ $r=0.96 ; n=52$

Spectrofluorimetric enzymatic method (Kitchen et al. 1978)

$r=0 \cdot 89 ; n=29$

Tributyrin (Castberg et al. 1975)
- $V R=$ Total volume of chemical or enzymatic reaction mixture

- LS = Length of stability of the absorbance of clarified mixture allowing spectrometric measurement 


\section{General procedure for the Clarifying Reagent use}

Here we present the general principle of the use of the Clarifying Reagent of Linden et al. (1987) and the required major precautions when improving one protocol.

First, a small volume of buffer containing the chemical reagent (for example TNBS for $\mathrm{NH}_{2}$ groups measurement) or the enzyme substrate (for example $p$-nitrophenyl butyrate for determination of lipase activity) is added to an aliquot of milk sample. The choice of the buffer, its molarity and $\mathrm{pH}$ are very important for protocol optimisation; these conditions must be suitable for the reaction and for the clarification step. Buffering power and $\mathrm{pH}$ are of great significance because the Clarifying Reagent is not effective when the final $\mathrm{pH}$ of the clarified mixture is below $8 \cdot 8-9 \cdot 0$.

Often, the reaction mixture is incubated at $37^{\circ} \mathrm{C}$ to allow the chemical or enzymatic reaction that lead to the formation of a coloured product in the medium to take place.

The Clarifying Reagent is added at the end of the chemical or enzymatic reaction. It contributes to stop these reactions by raising the $\mathrm{pH}$. Principal requirements are that the Clarifying Reagent does not hydrolyse the excess of chemical reagent or of enzyme substrate and does not destroy the reaction product that will be measured in the protocol. The advantage of the Clarifying Reagent is to render casein micelles and fat globules soluble which allows direct spectrophotometric measurements in milk without preliminary separation and extraction steps usually required in the common protocols. Nevertheless, it is sometimes necessary to add EDTA to aid the clarification (see NAGase protocol, Humbert et al. 1995) or EDTA with an enzyme inhibitor mixture both to aid the clarification and to completely stop the enzymatic reaction (see lipase protocol, Humbert et al. 1997). Generally after 3 or $5 \mathrm{~min}$ at $37^{\circ} \mathrm{C}$, the reaction mixture is limpid and can be used for direct spectrophotometric measurement. The clarified reaction mixture is stable for at least 10 to 30 min which allows time to make series of assays or to automate procedures. The loss of stability is shown by a turbidity that disturbs spectrophotometric measurement. Table 3 presents some comments on the procedures of some chemical and enzymatic protocols using the Clarifying Reagent.

\section{Chemical and enzymatic protocols using the Clarifying Reagent}

The Clarifying Reagent has been used in the chemical or enzymatic protocols reported in Table 2 and 3. The protocols for NAGase, lipase, plasmin and $\gamma$-glutamyl transpeptidase activities measurements reported in these tables have been established with the Clarifying Reagent of Linden et al. (1987).

Other protocols concerning lactoperoxidase, proteases and alkaline phosphatase had been first developed with the dissolving mixture of Linden \& Pâquet (1981). Thereafter, activity of these enzymes was measured by using the Clarifying Reagent of Linden et al. (1987), which required some modifications or adaptations of the previous protocols. The lactoperoxidase method established with the dissolving mixture (Linden et al. 1982) has been modified for $\mathrm{pH}$, buffer, substrate concentration and wavelength in order to use the Clarifying Reagent (Blel et al. 2001). For the determination of different proteolytic activities in milk with specific synthetic substrates, the only difference was the replacement of the $0.3 \mathrm{M}$ triethanolamine/ $\mathrm{HCl}$ buffer, $\mathrm{pH} 8.0$ (Linden et al. 1982; Humbert et al. 1982) by $0 \cdot 1 \mathrm{M}$-imidazole buffer, $\mathrm{pH} 8 \cdot 0$. To measure alkaline phosphatase activity, the molarity of the diethanolamine buffer $(\mathrm{pH} \mathrm{10.6)}$ has reduced from $0 \cdot 15$ to $0 \cdot 1 \mathrm{M}$ for use with the Clarifying Reagent.

Chemical protocols for the measurement of the $\mathrm{NH}_{2}$ groups with TNBS and of the $\mathrm{SH}$ groups with DTNB have been developed with the Clarifying Reagent (Humbert et al. 1990 and Guingamp et al. 1993 respectively). Preliminary studies using a NADH/NAD reaction have been carried out for ammonia and urea measurements in milk and whey (Guingamp et al. 1994). A rapid and simple protocol has also been proposed to estimate the effect of heat treatment on milk by measuring absorbance at $340 \mathrm{~nm}$ of the some coloured compounds formed during the Maillard reactions (Choukri et al. 1991; Guingamp et al. 1995).

In comparison with the other previously published methods, protocols using the Clarifying Reagent are time saving; for instance the lactoperoxidase protocol (Blel et al. 2001) is 5 times faster than the Rothenfusser reference method (Resmini et al. 1985), or the protease activity measurement is easier than that of Stead (1987) which requires a centrifugation step. Furthermore, all these protocols are repeatable with a good coefficient of variation (3-5\%), and are well correlated to the official reference methods (Table 3 ).

While all the protocols are established with bovine milk, NAGase and alkaline phosphatase protocols have also been applied to goat milk (Le Mens et al. 1994) and camel milk (Ramet \& Humbert, 1998) respectively.

\section{Analytical applications in the dairy industry of protocols using the Clarifying Reagent}

Analysis of raw milk

It is very important to rapidly determine the overall quality of raw milk after its arrival at the processing dairy. The first aspect of this analysis is to determine the integrity of the protein matter by measuring the $\mathrm{NH}_{2}$ groups, urea or ammonia in the milk. The second concerns endogenous and exogenous or bacterial protease and lipase activities present in milk. In addition, NAGase allows the detection of mastitis and to classify milks according to their quality (Humbert et al. 1995, 1996). Such analyses will 
indicate the potential of the milk to render high quality products.

\section{Analysis of heated milk}

Protein denaturation and Maillard Reactions are among the most significant and undesirable consequences of the heat treatment of milk. The Clarifying Reagent was used to quantify $\mathrm{SH}$ groups (Guingamp et al. 1993) and to measure absorbance at $340 \mathrm{~nm}\left(\mathrm{~A}_{340}\right.$; Choukri et al. 1991; Guingamp et al. 1995) which reflects the presence of coloured compounds derived from the Maillard reactions. Levels in $\mathrm{SH}$ and $\mathrm{A}_{340}$ values allow discrimination between raw, pasteurised, UHT-treated and sterilised milks and then to classify heated milk samples (Guingamp et al. 1999).

Due to their thermosensitivity, some indigenous enzymes are good indicators of the severity or effectiveness of heat treatment of milk and milk products. Clarifying Reagent has been used to measure alkaline phosphatase, lactoperoxidase and $\gamma$-glutamyltranspeptidase residual activities in heated milk and especially after pasteurisation (Blel et al. 2001, 2002). Plasmin activity has also been determined with the Clarifying Reagent to study its heat denaturation (Saint-Denis et al. 2001a, b).

\section{Analysis in cheese}

Ripening of cheeses can be followed either by the analysis of the protein and lipid fractions or by the measurement of enzyme activities such as total lipase or protease activities. Ammonia measurement protocol in milk (Guingamp et al. 1994) might also be adapted for monitoring cheese ripening. It is of interest to know if a cheese is manufactured with raw, thermised or pasteurised milk. The appearance of $\mathrm{NH}_{2}$ groups during ripening has been monitored using the Clarifying Reagent; to differentiate untreated Brie-type cheese and pasteurised Brie-type cheese (Humbert et al.

TQ1 1990). Recently, the "Clarifying Reagent" has also been used to measure residual $\gamma$-glutamyltranspeptidase in addition to alkaline phosphatase activities to differentiate Camembert made with raw milk from Camembert made with heated milk (Blel et al. 2002).

\section{References}

Barett NE, Grandison AS \& Lewis MJ 1999 Contribution of the lactoperoxidase system to the keeping quality of pasteurized milk. Journal of Dairy Research 66 73-80

Blel M, Guingamp M-F, Gaillard J-L \& Humbert G 2001 Improvement of a method for the measurement of lactoperoxidase activity in milk. International Dairy Journal 11 795-799

Blel M, Guingamp MF, Gaillard JL \& Humbert G 2002 Studies of the thermal sensitivity of $\gamma$-glutamyl transpeptidase measured with a modified test procedure and compared to that of alkaline phosphatase and lactoperoxidase in milk. Lait 82 555-566

Bosset JO \& Blanc BH 1977 [New, simple and economical method for routine determination of protein content of milk and some milk products]. Laitier Romand 53, 697-699 and Schweizerische Milchzeitung 103 325-326

Bosset JO, Blanc BH \& Plattner E 1977a Complete solubilization of whole milk by means of mixed solvents. I. Study of water-sodium Hydroxide - n-butylamine mixture. Mitteilungen aus dem Gebiete der Lebensmitteluntersuchung und Hygiene 68 225-239 and Travaux de Chimie Alimentaire et d'Hygiène 68 225-239

Bosset JO, Blanc BH \& Plattner E 1977b. Complete solubilization of whole milk by means of mixed solvents. I. Study of water-sodium Hydroxide - tetrahydrofuran mixture. Mitteilungen aus dem Gebiete der Lebensmitteluntersuchung und Hygiene 68 504-512 and Travaux de Chimie Alimentaire et d'Hygiène 68 504-512

Castberg HB, Solberg P \& Egelrud T 1975 Tributyrate as a substrate for the determination of lipase activity in milk. Journal of Dairy Research $\mathbf{4 2}$ 247-253

Choukri A, Guingamp MF, Humbert G \& Linden G 1991 A new analytical procedure to differentiate heated commercial milks. In: Strategies for food quality control and analytical methods in Europe Vol II, 563-568 Euro Food Chem VI, Hamburg (22-26th september 1991)

Guingamp MF, Humbert G, Choukri A \& Linden G 1989 Clarification of milk and milk products. La Technique Laitière ${ }^{\circ} 1036,35-38$

Guingamp MF, Humbert G \& Linden G 1993 Determination of sulfhydryl groups in milk using Ellman's procedure and the Clarifying Reagent. Journal of Dairy Science 76 2152-2155

Guingamp MF, Humbert G \& Linden G 1994 Rapid enzymatic determination of ammonia and urea in milks and wheys. XXIVth International Dairy Congress, Melborne (18-22th september) Brief Communications, Eb6, p124

Guingamp MF, Humbert G, Midon P \& Linden G 1995 Lactulose content and UV-absorbance measurement. To differentiate heated commercial milks. In: Current status and future trends in analytical food chemistry Vol III, 684-687 Euro Food Chem VIII, Vienna (18-20th september)

Guingamp MF, Humbert G, Midon P, Nicolas M \& Linden G 1999 Screening procedure for evaluating heat load in commercial milks. Lait 79 457-463

Hélaine E 1977 Determination of ammonia in milk by a specific electrode. Industries Alimentaires et Agricoles 94, 581-589

Humbert G, Desnouveaux F \& Linden G 1982 Application of total dissolution of colloidal components of milk to proteinasic activity determination. Lait 62 427-434

Humbert G, Guingamp MF, Kouomegne R \& Linden G 1990 Measurement of proteolysis in milk and cheese using trinitrobenzene sulphonic acid and a new dissolving mixture. Journal of Dairy Research 57 143-148

Humbert G, Guingamp MF, Choukri A \& Linden G 1995 Method for the measurement of $\mathrm{N}$-acetyl- $\beta$-D-glucosaminidase activity in bovine milk. Journal of Dairy Research 62 369-372

Humbert G, Guingamp MF, Choukri A \& Linden G 1996 Classification of bovine milk samples by using a new $\mathrm{N}$-acetyl- $\beta$-D-glucosaminidase activity measurement. Milchwissenschaft 51 63-65

Humbert G, Guingamp MF \& Linden G 1997 Method for the measurement of lipase activity in milk. Journal of Dairy Research 64 465-469

International Dairy Federation 1987 Detection of phosphatase activity. Standard 87A, Brussels, Belgium

Kitchen BJ, Middleton G \& Salmon M $1978 \mathrm{~N}$-acetyl- $\beta$-Dglucosaminidase and its significance in the detection of abnormal udder secretions. Journal of Dairy Research 45 15-20

Kouomegne R, Bracquart P \& Linden G 1984 Application of transparisation to enumerate milk microorganisms. Lait $\mathbf{6 4} 418-435$

Le Mens P, Dalmas S \& Humbert G 1994 Relationships between the activity of N-acétyl-glucosaminidase (NAG-ase), the cells amount, the coagulability of milk and the infectious state of the goat. In: Somatic cells and milk of small ruminants. International Symposium of Bella, Italy (25-27th september)

Linden G \& Pâquet D 1981 Alkaline phosphatase activity in transparent milk and cream. Journal of Dairy Science 64 568-571 
Linden G, Humbert G, Desnouveaux F \& Picard J 1982 Application of total dissolution of milk to enzymic activities determinations. Lait 62 209-219

Linden G, Kouomegne R, Guingamp MF \& Humbert G 1987 Reagent for rendering biological fluids transparent and its analytical applications. European patent application EP 0246978 B1, 10pp

More S \& Stein WH 1954 A modified ninhydrin reagent for the photometric determination of amino acids and related compounds. Journal of Biological Chemistry 211 907-913

Nakaï S \& Anh Chi Le 1970 Spectrophotometric determination of protein and fat in milk simultaneously. Journal of Dairy Science $\mathbf{5 3}$ 276-278

Owen JA \& Andrews AT 1984 A procedure for the complete clarification of milk of various species and its suitability for use with colorimetric measurements. Journal of Dairy Research 51 307-315

Patel SS \& Wilbey RA 1994 Thermal inactivation of -glutamyl transpeptidase and enterococcus faecium in milk-based systems. Journal of Dairy Research 61 263-270
Ramet JP \& Humbert G 1998 Heat sensitivity of alkaline phosphatase from camel's milk XXVth International Dairy Congress, Aarhus (21-24th september) Brief Communications, 256

Resmini P, Tripiciano C, Rampilli M \& Lodi R 1985 Some aspects of quality control of consumption milk. La Rivista dalla Societa Italiana di Scienza dell' Alimentazione 14 187-196

Saint-Denis T, Gaillard JL \& Humbert G 2001a Heat inactivation of native Plasmin, Plasminogen and Plasminogen Activators in bovine milk: a revisited study. Lait $\mathbf{8 1} 715-729$

Saint-Denis T, Humbert G \& Gaillard JL 2001b Enzymatic Assays for Native Plasmin, Plasminogen and Plasminogen Activators in bovine milk Journal of Dairy Research 68 437-449

Stead D 1987 Assay of proteinases of psychrotrophic bacteria in milk using Hide Powder Azure and a simple procedure for clarification of milk. Journal of Dairy Research $\mathbf{5 4} 295-302$

Yoshino U, Wilson HK \& Herreid EO 1962 Amperometric titration of sulfhydril and disulfide groups in milk proteins. Journal of Dairy Science 45 1459-1464 